\title{
Marine Sediments: Processes, Transport and Environmental Aspects
}

\author{
Marcello Di Risio ${ }^{1}$, Donald F. Hayes ${ }^{2}$ and Davide Pasquali ${ }^{1, *(1)}$ \\ 1 Environmental and Maritime Hydraulic Laboratory (LIam), Department of Civil, Construction-Architectural \\ and Environmental Engineering (DICEAA), University of L'Aquila, P.le Pontieri, 1, Monteluco di Roio, \\ 67040 L'Aquila, Italy; marcello.dirisio@univaq.it \\ 2 U.S. Army Engineer Research and Development Center, Engineer Research and Development Center, \\ Environmental Laboratory 3909 Halls Ferry Road, Vicksburg, MS 39180-6199, USA; \\ Donald.F.Hayes@usace.army.mil \\ * Correspondence: davide.pasquali@univaq.it
}

Received: 23 March 2020; Accepted: 26 March 2020; Published: 2 April 2020

Keywords: marine sediment; contaminated sediment management; coastal sediment transport; harbor siltation; dredging; water quality; coastal engineering; coastal defence system; mathematical modelling; engineering practice

\section{Introduction}

In recent years, increasing attention has been paid to water quality and environmental aspects related to sediment transport driven by both ambient forcing and human activities. The increasing attention paid to this wide topic is also exacerbated by the exploitation of the coastal zone for economic, touristic and social reasons (e.g., [1]). Indeed, estuarine, coastal, and harbor areas often undergo operations that temporarily increase sediment transport, e.g., to nourish beaches, to maintain navigation channels, and to remove contaminated sediment primarily to support their use. For example, beach maintenance is required to counteract erosion processes that degrade beach quality. Sand has to be dredged and moved to nourish beaches (e.g., [2]). Moreover, harbor areas and navigation channels require maintenance dredging (e.g., [3]) to allow the regular circulation of the vessels and, in some cases, to remove contaminated sediments.

Particular interest is focused on water quality and environmental aspects related to sediment transport driven by anthropogenic activities. The impact of these activities on water quality (e.g., [4]) and on the human health is a significant public concern (e.g., [5]). Therefore, it is important to have reliable tools able to provide a realistic forecasts of the plume dispersion (e.g., [6-9]). Hence, much research is needed related to the sediment processes, transport, and related environmental aspects of marine sediments.

The aim of this Special Issue is to collect novel research results to improve knowledge and to propose new tools in this field. The issue collected five papers that cover different aspects of coastal and ocean engineering, chemical oceanography, geology, and geomorphology using different approaches and instruments. Some of the studies used numerical models $[10,11]$, others acquired and analyzed field data regarding chemical [12] or geomorphological aspects of the ocean [13] while Lisi et al. [14] suggested a mathematical modeling framework to analyze the effects of sediment handling operations.

The core aspects of each paper are synthesized in the following section.

\section{Papers Details}

Hu et al. [10] investigate the important aspect of spillover of sediments due to the occurrence of typical tidal processes. The study was devoted to analyzing the case study of the Yangtze River's 
Estuary. They proposed a 2D numerical model based on the resolution of the depth-averaged 2D shallow water equations. The model is able to simulate the tidal flow, the sediment transport, and eventually the bed evolution in the estuary. Moreover, it allows giving a quantitative estimation regarding the spillover of water and sediment in the analyzed river. They used a high-resolution unstructured grid covering a great part of the river estuary (more that $600 \mathrm{~km}$ ) to reproduce the Yangtze Estuary. The validation of the results against field data showed the good performances of the model in reproducing tidal levels, sediment concentration, and depth-averaged velocity.

Botsou et al. [12] analyzed the aspects related to metals' mobility in the water column, focusing their attention on Antinioti Lagoon and Corfu Island. In particular, they investigated the processes responsible for the mobility of metals both in and beyond the transitional fresh-saline water interface. They acquired water samples in two sampling campaigns, as well as surface and core sediments during only the first and second campaigns, respectively. These data were analyzed by means of trace metal analysis. They also performed a statistical analysis to evaluate the significant differences in terms of metal concentrations.

Johnson et al. [13] investigated the role of hurricanes on the modification of the rocky coastline in the Gulf of California, in the Ensenada Almeja in particular. They acquired field data to classify the weight and density of the rocks and performed a study on the hydrodynamic forces needed to move the largest boulders in the site. Geological and lithological characterization of the study area was performed by the authors. Moreover, they collected an aerial photo to map the coastal boulder bed of Ensenada Almeja. In this way, boulder shapes and sizes were evaluated and correlated with the wave heights required to lift the rocks from the bedrock.

Lisi et al. [14] proposed an integrated modeling approach useful for the simulation of sediment dispersion in several types of coastal areas (i.e., semi-enclosed basins and off-shore areas). At first, the attention is focused on the definition of sediment resuspension sources. Then, a definition of the level of accuracy that should be required in modeling activities is proposed. Moreover, they proposed a wide spectrum of possible modeling approaches that could be used by contractors and controlling authorities for scheduling and performing sediment handling activities, giving also a methodological approach useful to read and interpret the numerical results. They also underlined the importance of a modeling-monitoring feedback system.

Kuznetsova and Saprykina [11] analyzed how the beach profile is influenced by the location of underwater bars. They performed this study by using a numerical model with attention paid to the time scale of a given storm. The experiments were numerical; however, they used realistic boundary conditions and wave climate. The results reveal a direct correlation between the location of the underwater bar and the shoreline. Moreover, they found an inverse correlation between the retreat of the shoreline and low-frequency wave heights occurring at the coast.

Author Contributions: All authors contributed equally to this manuscript. All authors have read and agreed to the published version of the manuscript.

Funding: This research received no external funding.

Acknowledgments: We want to express our sincere thankfulness to all the authors and the reviewers.

Conflicts of Interest: The authors declare no conflict of interest.

\section{References}

1. Di Risio, M.; Bruschi, A.; Lisi, I.; Pesarino, V.; Pasquali, D. Comparative analysis of coastal flooding vulnerability and hazard assessment at national scale. J. Mar. Sci. Eng. 2017, 5, 51. [CrossRef]

2. Di Risio, M.; Lisi, I.; Beltrami, G.; De Girolamo, P. Physical modeling of the cross-shore short-term evolution of protected and unprotected beach nourishments. Ocean Eng. 2010, 37, 777-789. [CrossRef]

3. Nichols, M.M.; Howard-Strobel, M.M. Evolution of an urban estuarine harbor: Norfolk, Virginia. J. Coast. Res. 1991, 7, 745-757. 
4. $\quad$ Bridges, T.S.; Ells, S.; Hayes, D.; Mount, D.; Nadeau, S.C.; Palermo, M.R.; Patmont, C.; Schroeder, P. The Four rs of Environmental Dredging: Resuspension, Release, Residual, and Risk; Technical Report; Engineer Research and Development Center: Vicksburg, MS, USA, 2008.

5. Feola, A.; Lisi, I.; Venti, F.; Salmeri, A.; Pedroncini, A.; Romano, E. A methodological modelling approach to assess the potential environmental impacts of dredging activities. In Proceedings of the Dredging Dredging Days, Innovative Dredging Solutions for Ports, Rotterdam The Netherlands, 5-6 November 2015.

6. Je, C.H.; Hayes, D.F. Development of a two-dimensional analytical model for predicting toxic sediment plumes due to environmental dredging operations. J. Environ. Sci. Heal. Part A 2004, 39, 1935-1947. [CrossRef] [PubMed]

7. Je, C.; Hayes, D.F.; Kim, K.S. Simulation of resuspended sediments resulting from dredging operations by a numerical flocculent transport model. Chemosphere 2007, 70, 187-195. [CrossRef] [PubMed]

8. Shao, D.; Gao, W.; Purnama, A.; Guo, J. Modeling dredging-induced turbidity plumes in the far field under oscillatory tidal currents. J. Waterw. Port Coast. Ocean Eng. 2017, 143, 06016007. [CrossRef]

9. Di Risio, M.; Pasquali, D.; Lisi, I.; Romano, A.; Gabellini, M.; De Girolamo, P. An analytical model for preliminary assessment of dredging-induced sediment plume of far-field evolution for spatial non homogeneous and time varying resuspension sources. Coast. Eng. 2017, 127, 106-118. [CrossRef]

10. Hu, D.; Wang, M.; Yao, S.; Jin, Z. Study on the Spillover of Sediment during Typical Tidal Processes in the Yangtze Estuary Using a High-Resolution Numerical Model. J. Mar. Sci. Eng. 2019, 7, 390. [CrossRef]

11. Kuznetsova, O.; Saprykina, Y. Influence of underwater bar location on cross-shore sediment transport in the coastal zone. J. Mar. Sci. Eng. 2019, 7, 55. [CrossRef]

12. Botsou, F.; Karageorgis, A.P.; Paraskevopoulou, V.; Dassenakis, M.; Scoullos, M. Critical Processes of Trace Metals Mobility in Transitional Waters: Implications from the Remote, Antinioti Lagoon, Corfu Island, Greece. J. Mar. Sci. Eng. 2019, 7, 307. [CrossRef]

13. Johnson, M.E.; Guardado-France, R.; Johnson, E.M.; Ledesma-Vázquez, J. Geomorphology of a Holocene Hurricane Deposit Eroded from Rhyolite Sea Cliffs on Ensenada Almeja (Baja California Sur, Mexico). J. Mar. Sci. Eng. 2019, 7, 193. [CrossRef]

14. Lisi, I.; Feola, A.; Bruschi, A.; Pedroncini, A.; Pasquali, D.; Di Risio, M. Mathematical Modeling Framework of Physical Effects Induced by Sediments Handling Operations in Marine and Coastal Areas. J. Mar. Sci. Eng. 2019, 7, 149. [CrossRef] 